\title{
"Olho por olho, dente por dente": $O$ erro e o castigo na bíblia e na ciência do direito
}

\section{"An eye for an eye a tooth for a tooth": error and punishment in the bible and in the science of law}

\author{
Rodrigo Rios Faria de Oliveira ${ }^{1 *}$
}

\begin{abstract}
RESUMO
O estudo abordará as questões normativas legais contidas na Torah, e suas retomadas e reformulações na ciência do direito, ocupando-se das linguagens jurídica e teológica, muitas vezes ininteligível, devido ao formalismo, que provoca o "efeito de desconhecimento" sobre o texto religioso, mais propriamente na questão do "olho por olho, dente por dente". Verificará, assim, as questões acerca do erro e do consequente castigo e ou punição contidas na Bíblia, em Deuteronômio, e as possíveis relações para com a ciência do Direito. Dessa forma, procurará observar concepção de lei presente na Torah, a fim de explicitar as iluminações que a tradição bíblica pode oferecer para o direito moderno e, dessa forma, postular uma prática do direito mais humanizadora.
\end{abstract}

Palavras-Chave: Teologia; Lei; Direito Mosaico; Direito.

\begin{abstract}
The study will address the legal normative issues contained in the Torah, and its resumptions and reformulations in the science of law, dealing with the legal and theological languages, often unintelligible due to formalism, which causes the "ignorance effect" on the religious text, more specifically on the issue of "an eye for an eye, a tooth for a tooth". Thus, it will verify the questions about the error and the consequent punishment and/or punishment contained in the Bible, in Deuteronomy, and the possible relations with the science of Law. Thus, it will seek to observe the conception of law present in the Torah, in order to explain the illuminations that the biblical tradition can offer to modern law and, in this way, postulate a more humanizing practice of law.
\end{abstract}

Keywords: Theology; Law; Mosaic Law; Right.

\footnotetext{
${ }^{1}$ Universidade do Vale do Sapucaí - UNIVÁS.

* E-mail: profdrrodrigooliveira@gmail.com
} 


\section{INTRODUÇÃO}

"E não o olharás com piedade; alma por alma, olho por olho, dente por dente, mão por mão, pé por pé.”(Devarim 19:20)

Ao verificarmos a passagem do Devarim 19:21, entre outras passagens contidas no livro do Tanah, temos que a questão relacionada à justiça trata-se de uma preocupação da Halacha.

Assim sendo, inúmeras são os dizeres aos juízes a fim de que os mesmos ajam com justiça, como podemos encontrar, exemplificando, em Levítico (Vaicrá) 19:18: "Não te vingarás e nem guardarás ódio contra os filhos de teu povo, e amarás o teu próximo como a ti mesmo - Eu sou o Eterno!

Há de notarmos, frente ao direcionamento de justiça, contido em vários momentos do Tanah, um lema de caráter social, o que podemos perceber questões principiológicas de direito processual.

Mesmo diante da conhecida Lei de Talião, sabido é que as normas judaicas refletiam, como ainda refletem, uma preocupação com a aplicabilidade da justiça, buscando, dessa forma, afastar-se de penalizações injustas.

Percebemos que, desde os primórdios, tanto a religião quanto o Direito o regiam o convívio dos homens, coexistiam e eram harmônicos. As sociedades compreendiam isso de forma una. Essa noção vivia no seio das sociedades e compunha suas bases morais. Davam-lhes não só o sentimento de pertencer à uma sociedade cujos valores eram compartilhados entre os indivíduos como permitia que pudessem trilhar um caminho rumo à felicidade.

Ao analisarmos a Torah, em seu primeiro livro, Bereshit, conhecido como "O Gênesis", poderemos perceber como a crença e o Direito estão intimamente ligados, explicando, simbolicamente, a complexidade da vida humana.

Ao adentrarmos nos preceitos legais, na atualidade, em nosso contexto constitucional e infraconstitucional, temos o princípio da dignidade humana, onde vidas 
estão envolvidas, pois muitos já mataram e já morreram por dignidade. Para During, dignidade é uma "qualidade intrínseca da pessoa humana, é irrenunciável e inalienável, constituindo elemento que qualifica o ser humano como tal e dele não pode ser destacado" (DURIG apud SARLET, 2011, p. 42).

O princípio da dignidade da pessoa humana é um dos princípios maiores que estão fundamentados na Constituição Federal de 1988, já que é considerado um dos fundamentos da República Federativa do Brasil.

O respeito ao referido princípio da dignidade da pessoa humana traz uma proteção à integridade física, moral e também individual e espiritual do ser humano. Portanto, o Direito possui sua razão de existir no homem, devendo o mesmo ser instrumento com o objetivo de impedir todo tipo de degradação do gênero humano.

\section{A LEI DE TALIÃO}

Em uma primeira análise, o jus talionis salta aos olhos quando se analisa o Pentateuco, mas não é de se admirar, já que a lei de Talião também era recepcionada pelos diversos sistemas penais vigentes na época.

O Código de Hamurabi (cerca de 1750 a.C) segundo Meister (2007) é um bom exemplo disso:

$196^{\circ}$ - Se alguém arranca o olho a um outro, se lhe deverá arrancar o olho.

$197^{\circ}$ - Se ele quebra o osso a um outro, se lhe deverá quebrar o osso.

$200^{\circ}$ - Se alguém parte os dentes de um outro, de igual condição, deverá ter

partidos os seus dentes.

$202^{\circ}$ - Se alguém espancar outro mais elevado que ele, deverá ser espancado

em público sessenta vezes, com o chicote de couro de boi.

$206^{\circ}$ - Se alguém golpeia outro em uma rixa e lhe faz uma ferida, ele deverá

jurar: "Eu não o golpeei de propósito", e pagar o médico.

$209^{\circ}$ - Se alguém atinge uma mulher livre e a faz abortar, deverá pagar dez

siclos pelo feto. 
$210^{\circ}$ - Se essa mulher morre, se deverá matar o filho dele.

O conceito do jus talione segundo Meister (2007) é o de que a punição por um determinado crime ou delito não pode ser fora da proporção do ato cometido, ou seja, não se pode tomar vida por dente ou mão por olho e assim por diante.

Temos aqui o princípio da proporcionalidade entre o crime, ou mal causado, e a pena do crime, ou retribuição do mal, que pode ser visto nesta passagem: "Mas, se houver desastre (de morte na mulher) - darás (indenização de ) alma por alma, olho por olho, dente por dente, mão por mão, pé por pé, queimadura por queimadura, ferida por ferida, contusão por contusão.” (Shemot 21,23-25)

O autor acredita que a universalidade do princípio da Lei de Talião no ambiente antigo é um argumento a favor de que se trata de um princípio de origem divina ou natural.

Aponta como esclarecimento para isso, o fato de que várias leis já eram conhecidas pelos patriarcas, conforme o texto de Bereshit 26,5: "Porque Abrahão escutou Minha voz e guardou Minha sentença, Meus mandamentos, Meus estatutos e Minhas leis."

É verdade que no Pentateuco encontram-se passagens em que os homens aplicam a justiça conforme a vingança privada, ou a Lei de Talião, mas é ingênuo supor que esse princípio seja de origem Divina, só porque era utilizado no contexto cultural da época.

Ademais, a Torah relata a história não de forma científica, mas conforme as crenças do povo hebreu antigo.

Contudo, o autor acerta quando ressalta que:
A Lei de Talião é dada para regular as relações sociais desequilibradas em diversos âmbitos, tais como crimes e acidentes contra a pessoa, a comunidade ou mesmo a propriedade. Caso não houvesse lei reguladora, estes processos acabariam em ciclos criminosos de vingança e opressão dos socialmente mais fracos, com respostas desproporcionais e injustas. (Meister, 2007, p. 61)

Meister (2007) reitera que, longe de constituir um meio de vingança pura e simples, a lei de talião era "um ato de retribuição necessária, tanto como punição para o indivíduo que comete o crime quanto para o ambiente social, visando prover meios para a reeducação do criminoso e também inibir outros delitos.” É óbvio que aí está latente o 
germe da moderna principiologia do Direito Penal, mas com suas peculiaridades da época, principalmente no que concerne à sua religiosidade.

Vejamos o contexto da Torah:

E por certo o vosso sangue de vossas almas requererei; da mão de todo animal a requererei; e da mão do homem; da mão do homem que é como seu irmão, requererei a alma do homem. Aquele que derramar o sangue do homem, pelo homem terá seu sangue derramado, pois à imagem de Deus fez o homem" (Bereshit 9,5-6)

Meister (2007) também afirma que a "ira divina" muito citada nas Escrituras revela que "o anseio da vingança não é ilegítimo, mas Deus o regula em virtude do estado de pecado do homem e coloca a si mesmo e ao Estado como legítimos vingadores."

\section{A JUSTIÇA PROFÉTICA}

Gardner (1965, p. 63) nos demonstra que a lei e a profecia hebraicas primitivas já haviam aceito que a justiça Divina consistia de retribuições a ações boas e castigos a ações más, de maneira proporcional e retributiva ao bem e ao mal praticado pelos homens, mas esta visão foi, com o tempo, reconhecida como contrária à experiência.

Os últimos profetas, Jó e alguns dos salmistas, menciona Gardner (1965), foram levados a rejeitar a noção primitiva de que a piedade é recompensada nesta vida em termos de prosperidade material.

O sofrimento não pode ser bem compreendido como castigo divino para a transgressão do homem; pelo contrário, deve ser encarado como parte de um processo pelo qual as almas dos homens são disciplinadas e testadas (Dt 8,2-5; S1 118,18; Pv 3,1112), e como o sofrimento vicário do inocente pelo culpado (Is 52,13-53,12). (Gardner, 1965 , p. 64)

Assim, o citado autor expõe o fato de que o sentido de justiça contido no Antigo Testamento também sofreu uma evolução, da ingênua retribuição na época mais primitiva ao conceito mais realista e universalista dos profetas, a partir do nono século a.C.

O profeta, para Berkhof (1990, p. 359) é alguém que fala da parte de Deus. É alguém que recebe revelações, que está a serviço de Deus, particularmente como mensageiro, e que fala em seu nome. 
$\mathrm{O}$ autor assevera que o dever dos profetas consistia em revelar a vontade de Deus ao povo. Isso podia ser feito através de admoestações e exortações, promessas gloriosas ou censuras severas. Eles eram os intérpretes da lei, especialmente nos seus aspectos morais e espirituais.

Facciolla (2005) atesta que o mundo mostrado pelos profetas é um mundo cheio de injustiças, iniquidades, escravo do pecado desde que este penetrou no mundo. Concluindo, assevera que o conceito de justiça para os profetas é o resultado do relacionamento dialético do conhecimento e sabedoria, e que deste relacionamento brota o conceito ético-político de justiça.

\section{A CONDIÇÃo HUMANA FRENTE AOS DITAMES DO DIREITO E DA RELIGIÃO}

Qualquer sociedade, cujo ideal sejam os valores e as virtudes humanas mais sublimes, tem sua fundação baseada em natureza religiosa, seja ela decorrente de uma fé genuína ou mitológica. Não há Império de natureza laica que tenha subsistido às eras e aos tempos. Todos os impérios laicos, como o de Bonaparte ou de Hitler, Stalin ou Vargas, duraram, em média, poucos anos. E, em seu conteúdo, não possuíram nenhum dos mais elevados padrões do espírito humano. Porém, ao contrário, todo império de grandeza histórica, e que produziu grandes feitos em nome da humanidade, possui em suas bases alguma adesão religiosa (NASSER, 2014, p. 128-129).

Não há como estudar, por exemplo, sociedades clássicas medievais cristãs ou, então, as judaicas ou islâmicas, romanas ou gregas, sem que se entenda isso pela noção do religioso. Não há explicação militar nem econômica capaz de suprir isso que não seja a religiosa. E, acerca desse ponto, é fundamental que o estudioso do assunto não tenha preconceitos nem esteja contaminado por ideologias modernas, a fim de que sua compreensão real do assunto não seja afetada.

Até o ano de 1314, quando Felipe IV, o Belo (NASSER, 2014, p. 133), declarouse rei absolutista, extinguindo de vez a intervenção do poder espiritual (religioso) sobre o temporal (poder político), era comum que nas sociedades anteriores seus líderes contemplassem uma dupla função, a de sacerdote (pois serviria como uma bússola moral e espiritual ao povo) e a de político (no sentido de que seria um juiz e administrador, que julgaria os problemas de seu povo bem como tomaria decisões importantes acerca da 
política local), ou então que, ao exercer o poder político, respeitassem as regras morais e éticas de cunho religioso do poder espiritual. Isso pode ser visto em vários momentos da História Humana, como no Império Romano (MONTANELLI, 1961, p. 19-27), no Império Grego ( MONTANELLI,1962, p. 50), na História do Povo Judeu, com o Êxodo, liderada por Moisés (Livro de Êxodo), dentre várias outras sociedades.

Desde os primórdios, a religião e o Direito, o mundo das leis que regiam o convívio dos homens, coexistiam e eram harmônicos. As sociedades compreendiam isso de forma una. Essa noção vivia no seio das sociedades e compunha suas bases morais. Davam-lhes não só o sentimento de pertencer à uma sociedade cujos valores eram compartilhados entre os indivíduos como permitia que pudessem trilhar um caminho rumo à felicidade. E, quando dizemos "felicidade", não estamos tratando de um mero sentimento passageiro, que o mundo moderno tende a confundir com "momentos de alegria", mas, antes, tratamos de um conceito aristotélico, que se refere a um fim humano que está alocado em um ponto superior e transcendente ao homem, e que o motiva a viver independentemente do "mundo das sensações", quer ele passe por dificuldades ou bençãos, tristezas ou alegrias.

Se pegarmos, por exemplo, a Bíblia e estudarmos logo, de plano, seu primeiro livro, "O Gênesis", poderemos perceber como a crença e o Direito estão intimamente ligados. E mais. Como isso, simbolicamente, o texto sagrado explica a complexidade da vida humana.

No Cap. II do Gênesis, no v. 3, é dito que Deus, no dia sétimo, cessou de produzir todas as suas obras, que tinha criado. No v. 7, é descrita a criação do homem. Em seguida, no v. 9, tem-se a narração sobre a criação da árvore da vida e a da ciência do bem e do mal. No v. 15, é dito que Deus concedeu a Terra ao homem para que ele a horte e guarde. E, para finalizar nosso exemplo, no v. 17, é dito que Deus ordena ao homem que não coma do fruto da árvore da ciência do bem e do mal. Veja: No v. 3, com a cessão das obras, Deus, além de inventor do mundo, passa a ser Juiz sobre o mundo e ao homem, pois dali em diante Ele ditará normas que o homem deve cumprir e respeitar. Porém, se as violar, alguma sanção surgirá. No v. 7, é dito que o homem é formado do limo da terra, isto é, do barro, a junção de terra e água. Vale dizer, ao mesmo tempo em que o homem possui um espírito, ele possui também um corpo físico (algo que filósofos como Sócrates, Platão e Aristóteles perceberam por meio da razão, e não através da Revelação, como ocorre com o Cristão). No v. 9, em que há a descrição sobre a árvore da vida e a da ciência 
do bem do mal, podemos compreender, sob uma análise simbólica tradicional que: A vida do homem é colocada sobre uma tensão da qual ele não tem o menor poder, mas sobre a qual ele deve conviver e tomar alguma atitude ou escolha sobre ela. Isto é, o homem tem que constantemente decidir se escolhe a vida do espírito (a árvore da vida) ou se prefere a vida da matéria (a árvore da ciência do bem e do mal). No v. 15, quando é dito que Deus colocou o homem sobre o paraíso - o mundo original - para hortar e o guardar, podemos compreender, simbolicamente, que Deus concedeu a Terra ao homem para que ele a governasse, para que ele a administrasse, e com zelo, pois se tratava de um presente de Deus. Já no v. 17, quando trata de que o homem não deve comer do fruto da árvore da ciência do bem e do mal, pode-se compreender que, simbolicamente, ao homem sempre haverá a imposição de algum limite moral do qual ele não deve ultrapassar, sob pena de sua transgressão causar-lhe uma queda ontológica (Nasser, 2014).

Note que, na explicação acima, embora tenhamos tratado de análises simbólicas tradicionais, não se deixou de lado a análise acerca da correlação entre um Direito atemporal, existente entre Deus e o homem, nem com aquela relacionada à vida do próprio homem, em si.

Outro exemplo que podemos dar é acerca do mito grego de "As Eumênides", em que é instaurado um tribunal para julgar Orestes, que matara sua mãe Clitemnestra e o amante dela, Egisto, em vingança por terem matado seu pai, Agamêmnon. Antes de acontecer o julgamento, Orestes é perseguido o tempo todo pela figura das Erínias (também chamadas de "Fúrias"), três deusas antecedentes a Zeus, que têm, dentre várias funções, a de perseguir os matricidas. A deusa Atena toma ciência dessa perseguição, e, em nome da Justiça, propõe o julgamento de Orestes. As Erínias fazem as acusações contra Orestes; o deus Apolo faz a defesa de Orestes; há um empate na votação do povo ateniense e, por fim, Atena dá seu voto de Minerva, absolvendo Orestes do julgamento sumário - e sem direito de defesa - que as Erínias fariam sobre ele antes do julgamento. Após isso, por conselho de Atena, as Erínias são convertidas em Eumênides, agora deusas benevolentes. Simbolicamente, e em paralelo ao direito, tem-se aí uma estória que, além de servir de base moral à sociedade ateniense, servia como parâmetro e ideal de Justiça, pois pregava, antes mesmo de algum conjunto de normas legislativas humanas, o direito inato do ser humano em ter um julgamento justo, permeado pelo contraditório, e, também, em que a acusação fala primeiro e a defesa depois, para que não se tenha uma acusação viciada e ilegítima. 
Note, leitor, como as bases moral, ética e religiosa, nesses poucos exemplos, sempre estiveram entrelaças ao Direito, e este para com aquelas.

Pois bem. Embora o Direito sirva como instrumento para o exercício do poder temporal - como veremos mais adiante -, ele possui, em si, dimensões atemporais, como já salientamos anteriormente, uma vez que existente no mundo desde suas origens, quer o leitor tenha ou não alguma fé ou crença. O certo é que o Direito sempre foi constatado como uma permissão de Deus para o homem governar sobre o mundo, para o "hortar e guardar".

Visualizado esse assunto, passemos a estudar um pouco mais sobre essas questões da atemporalidade do Direito e suas relações com as acepções do divino.

O Direito tem como objetivo a ordem, a harmonia da vida dos seres humanos, ao bem comum, no sentido de que a vontade de cada homem não prejudique o bem alheio; isto é, deve haver uma combinação bela entre o bem de um com o dos demais (REALE, 2004, p. 59).

E é no homem que o Direito encontra sua medida, sua proporção e seu valor (REALE, 2004, p. 60). Não à toa a expressão "ubi societas, ubi ius" designa que "onde está a sociedade está o Direito". Se existisse no mundo apenas a fauna e a flora, o Direito sequer teria um rascunho de si. Pois o que seria do Direito sem o homem? Evidentemente, um nada.

A ordem jurídica que o Direito delineia é um fundamento inerente à vida em sociedade. É impossível, e aqui lembramos o leitor das lições de Aristóteles em " $A$ Política" (Aristóteles, 2017), que a sociedade exista sem estabelecer um esquema de convivência, composto por regras, castas, classes e hierarquias, dentre outras complexidades existentes no modo e na forma de a sociedade e o indivíduo se regrarem. É natural do homem que, mais cedo ou mais tarde, surgirá alguém na sociedade que velará pela ordem moral, outro pela ordem jurídica, um outro pela ordem econômica e um último, que obedecerá aos demais. É da essência do ser humano viver em sociedade bem como o é de desenvolver no seio de sua liberdade as vontades de seu espírito.

Pois, note, que a dificuldade real do Direito é esta: Permitir que o homem cumpra os deveres e as vontades sublimes de seu espírito e, ao mesmo, impedir que isso fira a dos demais à sua volta. Ao mesmo tempo em que o Direito se estabelece como um árbitro ao homem, ele se torna também seu libertador. 
Miguel Reale analisa que o Direito é composto de três aspectos que coexistem ao mesmo tempo, e que se estabelecem também em um mesmo tempo. Não há como dizer qual vem primeiro nem qual é depende desse ou daquele. A compreensão disso deve-se dar pelo seguinte fato: Não somos onipresentes nem oniscientes. E como estamos sujeitos à temporalidade do ser, dependemos de observar o mundo e os conceitos à nossa volta de forma esquematizada, tempo por tempo, "coisa por coisa", para somente depois compreender o assunto sob uma vista panorâmica. Pois bem. Os três aspectos componentes do sentido de Direito, constatados pelo Professor Reale, são: a) o aspecto normativo, como uma autêntica regra ao ser humano; b) o aspecto fático, eis que o Direito é algo real na vida do ser humano e c) o aspecto axiológico, no sentido de que o Direito é um valor de Justiça, um significado, sentido e motivo à norma e ao fato (REALE, 2004, p. 64-65).

Há um complexo processo de formação do juízo de valor sobre os comportamentos do homem. E, aqui, também se assenta o Direito, pois o resultado desse juízo de valor resultará na imposição de normas sobre os indivíduos dentro da sociedade. E, perceba, que não há como dizer "quando" nem "de que modo" se dá essa incorporação de normas. Ela também integra a natureza [leia-se "essência"] do homem e do Direito.

E é interessante notar que o Direito ao mesmo tempo em que nasce do homem, e para o homem, ele meio que desenvolve uma forma ou vida própria, porém sem se desvincular da atividade humana.

Exemplo disso é a característica da imperatividade do Direito - algo natural a ele, cujo teor não foi preciso nenhum homem inventá-lo ou dizer o porquê de ser assim (eis que impensável imaginar o Direito sem poder de império ou coercitividade) -, que impõe ao homem certa norma ou dever sobre si e às suas condutas em relação ao seu próximo, sob pena de alguma sanção caso a viole. E essa norma, assim como qualquer outra, expressa algo que "deve ser" (REALE, 2004, p. 34), um ideal a ser atingido. Esse "deve ser", contudo, é justamente aquele complexo de juízo de valor acerca do comportamento do homem.

Note que ali dentro há duas expressões importantíssimas ao entendimento da normatividade do Direito. Uma delas é a expressão “Juízo" é definido como o ato mental pelo qual se atribui uma característica ou qualidade a um ser ou ente. E essa ligação entre o sujeito de que se está a falar e sua qualidade pode ser de forma tão somente "indicativa" ou, então, “imperativa". A segunda é a expressão "sanção", que designa uma garantia ao cumprimento do "deve ser" violado (REALE, 2004, p. 34-35). 
Perceba que o Direito nunca está de fato completo, pois situado sempre em dois polos: O do "deve ser" (o ideal de Justiça a ser alcançado) e o do que "efetivamente é" (o que nem sempre corresponde ao ideal visado). Isso também não é motivo para causar espanto ao estudioso do tema, uma vez que o paradoxo existente nisso é da natureza do mundo e da vida do homem. Só existe a norma por haver a possibilidade de o homem a violar; só há o perdão porque o existe o pecado, e assim por diante.

Sobre esse ponto, ressaltamos a qualquer leitor ou estudioso a importância de se compreender que o Direito não está reduzido à mera compreensão de um conjunto de leis elaboradas por uma assembleia legislativa, que é alterada de tempos em tempos, e sequer a um conjunto de decisões dos tribunais. O Direito está além disso. Ele está relacionado ao homem, desde o seu estado de espírito até ao físico, desde o começo dos tempos.

Tal qual Aristóteles, para quem é natural que o homem constitua a polis, isto é, a cidade, um corpo social de indivíduos, o Professor Conselheiro José Maria de Avellar Brotero - primeiro professor de Curso Jurídico a ser nomeado no Brasil, em 1827 enxergava também que os governos são "uma necessidade absoluta" da sociedade civil, e, para que produzissem os resultados desejados pelo homem, deveria conter, em suas bases, a soberania (CONSELHEIRO BROTERO, 2007, p. 41-42).

Contudo, a soberania, para Conselheiro Brotero não era uma característica do governo, mas, sim, do povo (e esse raciocínio é pode ser alcançado pela seguinte pergunta: Se a soberania residisse no governo, e caso ele se extinguisse, onde ela residiria?). Ele conceituou "soberania" como o poder supremo que tem um povo de se reger e governar. É o grau mais elevado de dignidade e poder que nenhum homem tem como indivíduo, mas que somente o povo - considerado como nação - detém, e que se compõe pelas vontades e liberdades de todos os homens que formam esse povo. A "soberania", segundo ele, é a a super omnia, isto é, a justiça divina ou providência, pois, embora ela surja da união dos indivíduos na formação de um povo ou nação, e não resida em nenhum indivíduo, ela é um “dom” concedido por Deus ao povo para que governantes exerçam a autoridade e o Poder (CONSELHEIRO BROTERO, 2007, p. 33-35).

São palavras do Professor Conselheiro Brotero (2007, p. 35):

"Tudo neste mundo é organizado, existe e se move pelas leis do Supremo Ser; não é, portanto, erro o dizer-se que os reis governam pela graça de Deus, pois, se não houvesse vontade de Deus, os reis deixariam de ser reis (Salmo 136, vs. 18 e 19). É, porém, falso que os poderes 
políticos sejam conferidos por Deus aos soberanos. Poderes convencionativos tão vários como as mesmas convenções. Pelo contrário, Deus expressamente declarou que os povos escolhessem a forma de governo que muito bem quisessem - 'Então Jeová disse a Samuel: 'Dá ouvidos à sua voz', e todo o povo se foi a Galgala, e tornaram a receber ali a Saul por seu rei' $\left(1^{\circ}\right.$ L. dos Reis, cap. $8^{\circ}$, vs. 22 - cap. 11, vs. 15).”

Qualquer que seja a doutrina política ou o regime adotado por ela, cada uma possui sua própria noção acerca do assunto "legitimidade do poder". Ao conquistador ou ao monarquista, a legitimidade se dá pela espada e a Deus, e, também, pela sucessão; ao democrata, a legitimidade se dá pelo sufrágio universal; ao comunista, pela vontade da classe trabalhadora; ao nacional-socialista, no princípio do chefe etc (CONSELHEIRO BROTERO, 2007, p. 37, e SOUSA, 1976, p. 35-36). É da natureza da sociedade a existência do Poder; é da natureza do ser humano. E a legitimidade para exercício desse Poder, conforme salienta os professores Conselheiro Brotero e José Pedro Galvão de Sousa, decorrem da ordenação de Deus, autor da natureza.

Nos dizeres do Professor José Pedro Galvão de Sousa - posição da qual concordamos -, a “[...] autoridade, ou direito de obrigar os outros, só por essa origem superior pode explicar-se, pois Deus é o fundamento de toda obrigação moral e jurídica" (1976, p. 36). Segundo ele, tal qual afirmado pelo Conselheiro Brotero, Deus não designa em particular o sujeito nem a forma do poder, mas, sim, o poder e a autoridade de governar. O sujeito e a forma de governar decorrem de uma série de fatores humanos combinados com circunstâncias naturais e, sobretudo, com um elemento que a ciência, na maioria das vezes, não considera: A ação da Providência sobre as sociedades (SOUSA, 1976, p. 36).

O poder, segundo SOUSA (1976, p.38), pertence de forma originária ao que por uma superioridade em posição social, ou em inteligência, ou em recursos, praticou atos de soberania, com força necessária capaz de ser obedecido. Nos dizeres dele, o primeiro titular do poder ocupa a posição. Isto é, trata-se de uma posição que, inicialmente, está vaga, mas cujo titular a ocupou em primeiro. Isso pode se dar não só pela conquista da espada - como dirá o Professor Conselheiro Brotero - como pode ocorrer também por meio de consentimento dos demais que serão governados.

Porém, como o humano é um ser limitado, que não vive para sempre, a titularidade do poder é flexível. Pode ocorrer então, após a existência do titular originário, meios de 
transmissão do poder. E isso pode advir dos seguintes modos: a) Pela convenção (como uma eleição, por exemplo); b) pela sucessão (a linhagem hereditária, no caso das monarquias); c) a conquista (quando há o interesse de se pôr fim aos abusos e crimes de um governo iníquo) e d) por prescrição (quando há um governo irregular, que há tempo exerce o poder pacificamente, com verdadeiro espírito de justiça e equidade) (SOUSA, 1976, p. 39).

Modernamente, os Estados valem-se de Constituições para estabelecerem a investidura legítima do poder político. Ocorre que, atualmente, essas constituições possuem o mesmo sentido das leis fundamentais antigas, como aquelas sobre hereditariedade do poder monárquico, que podemos encontrar nas Escrituras Sagradas e, também, na Lei Sálica francesa, por exemplo (SOUSA, 1976, p. 40).

O grande problema das constituições atuais é o de não advirem do fruto de uma construção histórica baseada na realidade dos indivíduos que compõem a sociedade, mas, sim, por serem produto de uma invenção a jato de alguma ideologia de seu legislador. Uma constituição, que não respeita a tradição de seu povo, nem o homem concreto e real de sua sociedade, está fadada a ser alterada de anos em anos, justamente porque seus legisladores, ao invés de olharem para a felicidade espiritual visada pelos indivíduos de seu povo - algo que a ciência moderna, em grande parte, considera como acepção retrógrada, eis que confundem conceitos de cunho moral-religioso com religião e influências religiosas -, acreditam serem "seres iluminados", donos de uma "verdade forçada" por suas vontades, que em nada correspondem com a realidade e o homem concreto da sociedade (SOUSA, 1971, p. 7-15).

Desse modo, resta claro como a Religião, o Direito e a condição humana fazem parte da estrutura da realidade. Embora não comportem toda a estrutura da realidade, pois esta detém uma complexidade tão grande, que só pertence ao entendimento de Deus, temos de concluir que a aceitação da constatação dessas verdades não só produz um espírito sadio ao homem como o auxiliam a viver no melhor no mundo em que foi colocado.

Diante de tais considerações, torna-se viável expormos algumas considerações sobre a dignidade da pessoa humana, preceito esse de suma importância em nosso ordenamento, tanto constitucional quanto infraconstitucional.

\section{DA DIGNIDADE DA PESSOA HUMANA}


A dignidade envolve vidas, pois muitos já mataram e já morreram por dignidade, para During, dignidade é uma "qualidade intrínseca da pessoa humana, é irrenunciável e inalienável, constituindo elemento que qualifica o ser humano como tal e dele não pode ser destacado" (DURIG apud SARLET, 2011, p. 42).

O referido princípio encontra-se na Constituição Federal do Brasil, em seu artigo $1^{\mathrm{o}}$, in verbis:

Art. $1^{\circ}$ A República Federativa do Brasil, formada pela união indissolúvel dos Estados e Municípios e do Distrito Federal, constituise em Estado Democrático de Direito e tem como fundamentos:

III - a dignidade da pessoa humana;

Os direitos individuais do homem tiveram origem no antigo Egito e Mesopotâmia, onde já havia alguns mecanismos que eram utilizados para fazer a proteção do homem como ser individual na relação com o Estado.

Portanto, o maior desenvolvimento das declarações de direitos humanos fundamentais se deu mesmo após o século XVIII até o século XX. Já no Brasil a Constituição Política do Império do Brasil de 1824, nos artigos 107 e 108 onde já trazia a palavra dignidade, porém era somente para o Imperador e para a Imperatriz.

Já na Constituição da República Federativa do Brasil de 1967, no artigo 157, inciso II, traz a referência à valorização do trabalho, como o mesmo sendo uma condição da dignidade humana.

O princípio da dignidade da pessoa humana é um dos princípios maiores que estão fundamentados na Constituição Federal de 1988, já que é considerado um dos fundamentos da República Federativa do Brasil.

Sobre o assunto afirma Nelson Nery Júnior: 
Esse princípio não é apenas uma arma de argumentação, ou uma tábua de salvação para a complementação de interpretações possíveis de normas postas. Ele é a razão de ser do Direito. Ele se bastaria sozinho para estruturar o sistema jurídico. Uma ciência que não se presta para prover a sociedade de tudo quanto é necessário para permitir o desenvolvimento integral do homem, que não se presta para colocar o sistema a favor da dignidade humana, que não se presta para servir ao homem, permitindo-lhe atingir seus anseios mais secretos, não se pode dizer Ciência do Direito. Comprometer-se com a dignidade do ser humano é comprometer-se com sua Vida e com sua liberdade. É o princípio fundamental do direito. É o primeiro. O mais importante (NERY JÚNIOR, 2006, p. 119).

Com os mesmos passos de vários outros países, a Constituição Federal Brasileira dá ao princípio da dignidade da pessoa humana um caráter normativo amplo, já que demonstra reflexo mediante todo o sistema político, social e também jurídico. Também traz de forma veemente a importância que o Estado consegue atribuir à pessoa humana já que aquele existe pelo motivo desta.

Sobre o ser humano como o motivo de toda a atividade do estado, afirma Gustavo Tepedino:

A dignidade da pessoa humana torna-se o objetivo central da República, funcionalizando em sua direção a atividade econômica privada, a empresa, a propriedade, as relações de consumo. Trata-se não mais do individualismo do século XVIII, marcado pela supremacia da liberdade individual, mas de um solidarismo inteiramente diverso, em que a autonomia privada e o direito subjetivo são remodelados em função dos objetivos sociais definidos pela Constituição e que, em última análise, voltam-se para o desenvolvimento da personalidade e para a emancipação do homem (TEPEDINO, 2011, p. 501).

O referido princípio é de fundamental importância para que se respeite a dignidade da pessoa humana, inclusive vem sido falado com bastante frequência nos meios de comunicação, sendo feito comentários e analisando o mesmo por vários juristas.

A Constituição Federal de 1988 traz como fundamento do Estado Democrático de Direito, a dignidade da pessoa humana, porém alguns autores entendem que a mesma também deve ser um valor constitucional, conforme afirma Pietro de Jesús Lora Alarcón: 
O ser humano não pode ser objeto de humilhações ou ofensas, mas se deve reconhecer na sua essência de liberdade, responsabilidade e finalidade em si mesmo. Em função disso, a impossibilidade de degradação do ser humano impede redução do homem a mero objeto do Estado ou de terceiros, o que incluía impossibilidade de coisificação da pessoa, um ponto de não retorno da pessoa ao estado de simples coisa (ALARCÓN, 2014, p. 255).

A superioridade dos princípios da Constituição é sustentada pela existência dos que possibilitam a criação de um sistema interno de hierarquia dentro da própria Constituição, já que se encontram em um patamar acima das outras questões, desemprenhando uma força vinculante, principalmente no que diz respeito à atividade interpretativa.

Sobre o assunto, afirma Alexandre de Moraes:

Esse fundamento afasta a ideia de predomínio das concepções transpessoalistas de Estado e Nação, em detrimento da liberdade individual [grifei]. A dignidade é um valor espiritual e moral inerente à pessoa, que se manifesta singularmente na autodeterminação consciente e responsável da própria vida e que traz consigo a pretensão ao respeito por parte das demais pessoas, constituindo-se um mínimo invulnerável que todo estatuto jurídico deve assegurar, de modo que, somente excepcionalmente, possam ser feitas limitações ao exercício dos direitos fundamentais, mas sempre sem menosprezar a necessária estima que merecem todas as pessoas enquanto seres humanos (MORAES, 2013, p. 98).

O respeito ao referido princípio da dignidade da pessoa humana traz uma proteção à integridade física, moral e também individual e espiritual do ser humano, portanto, o Direito possui sua razão de existir no homem, devendo o mesmo ser instrumento com o objetivo de impedir todo tipo de degradação do gênero humano.

Sobre o referido princípio, afirma José Afonso da Silva:

A norma constitucional do artigo $5^{\circ}$, inciso LVII, garante a presunção de inocência por meio de um enunciado negativo universal: "ninguém será considerado culpado até o trânsito em julgado de uma sentença penal condenatória". O trânsito em julgado se dá quando a decisão não comporta mais recurso ordinário, especial ou extraordinário (SILVA, 2008, p. 159). 
Sobre a ação imediata dos princípios, isto acontece decorrente do funcionamento de parâmetros interpretativos e integrativos, já que demonstram suporte à ordem jurídica sob o aspecto de sistema.

Luiz Roberto Barroso explica que:

A dogmática moderna avaliza o entendimento de que as normas jurídicas, em geral, e as normas constitucionais, em particular, podem ser enquadradas em duas categorias diversas: as normas-princípio e as normas-disposição. As normas-disposição, também referidas como regras, têm eficácia restrita às situações específicas às quais se dirigem. Já as normas-princípio, ou simplesmente princípios, têm, normalmente, maior teor de abstração e uma finalidade mais destacada dentro do sistema (BARROSO, 2009, p. 153).

Sarlet conceitua a dignidade da pessoa humana como:

A qualidade intrínseca e distintiva reconhecida em cada ser humano que o faz merecedor do mesmo respeito e consideração por parte do Estado e da comunidade, implicando, neste sentido, um complexo de direitos e deveres fundamentais que assegurem a pessoa tanto contra todo e qualquer ato de cunho degradante e desumano, como venham a lhe garantir as condições existenciais mínimas para uma vida saudável, além de propiciar e promover sua participação ativa e corresponsável nos destinos da própria existência e da vida em comunhão com os demais seres humanos (SARLET, 2011, p. 61).

Conforme afirma Sarlet, somente depois da Segunda Guerra Mundial as Constituições começam a reconhecer expressamente a dignidade da pessoa humana, mas atualmente nem todos os países reconhecem a mesma expressamente. Sobre o assunto afirma Barroso:

O princípio da dignidade da pessoa humana identifica um espaço de integridade moral a ser assegurado a todas as pessoas por sua só existência no mundo. É um respeito à criação, independente da crença que se professe quanto à sua origem. A dignidade relaciona-se tanto com a liberdade e valores do espírito como com as condições materiais de subsistência. $\mathrm{O}$ desrespeito a este princípio terá sido um dos estigmas do século que se encerrou e a luta por sua afirmação um símbolo do novo tempo. Ele representa a superação da intolerância, da discriminação, da exclusão social, da violência, da incapacidade de aceitar o outro, o diferente, na plenitude de sua liberdade de pensar, de ser e de criar. Dignidade da pessoa humana expressa um conjunto de 
valores civilizatórios incorporados ao patrimônio da humanidade. O conteúdo jurídico do princípio vem associado aos direitos fundamentais, envolvendo aspectos dos direitos individuais, políticos e sociais. Seu núcleo material elementar é composto do mínimo existencial, locução que identifica o conjunto de bens e utilidades básicas para a subsistência física e indispensável ao desfrute da própria liberdade. Aquém daquele patamar, ainda quando haja sobrevivência, não há dignidade. $\mathrm{O}$ elenco de prestações que compõem o mínimo existencial comporta variação conforme a visão subjetiva de quem o elabore, mas parece haver razoável consenso de que inclui: renda mínima, saúde básica e educação fundamental. Há ainda, um elemento instrumental, que é o acesso à justiça, indispensável para a exigibilidade e efetivação dos direitos (BARROSO, 2009, p. 28).

Desde modo pode perceber-se que a Constituição Federal de 1988 traz a preocupação de que seja colocado o princípio da dignidade da pessoa humana em um ponto de destaque, ou seja, como realmente um fundamento da República Federativa do Brasil, partindo de uma perspectiva de Estado Democrático de Direito, para conseguir apresentar que o ser humano é alvo de uma moderna estrutura jurídica, e também para que seja esclarecido que qualquer prática que for reduzir à mesma à condição de coisa ou mesmo que quiser vir a privá-la dos meios que são necessários para a sua manutenção não será admitida.

Maria Garcia afirma que:

$\mathrm{Na}$ Constituição brasileira, a dignidade da pessoa humana figura entre os princípios fundamentais que estruturam o Estado como tal, portanto, inserindo-se entre os valores superiores que fundamentam o Estado, a dignidade da pessoa representará o crivo pelo qual serão interpretados não somente os direitos fundamentais mas, todo o ordenamento jurídico brasileiro nas suas variadas incidências e considerações (GARCIA, 2004, p. 57).

Existem muitos desdobramentos os quais são variados desse princípio, como norma fundamental, como o dever de ser observado em tudo e também por todos, inclusive no processo legislativo, e também na condição de valor, sendo o mesmo uma fonte que anima e justifica a existência do ordenamento jurídico.

A dignidade da pessoa humana é o fundamento dos direitos fundamentais, sendo que em favor da dignidade não pode existir dúvidas, devendo ser a realização concreta. Portanto, existem outros direitos fundamentais que são baseados na dignidade da pessoa 
humana, mesmo que estejam implícitos nos direitos que sejam expressamente positivados.

Sobre o vínculo que existe entre o princípio da dignidade da pessoa humana e os direitos fundamentais afirma Sarlet:

Verifica-se ser de tal forma indissociável a relação entre dignidade da pessoa e os direitos fundamentais que mesmo nas ordens normativas onde a dignidade ainda não mereceu referência expressa, não se poderá - apenas a partir deste dado - concluir que não se faça presente, na condição de valor informador de toda a ordem jurídica, desde que nesta estejam reconhecidos e assegurados os direitos fundamentais inerentes à pessoa humana. Com efeito, sendo correta, a premissa de que os direitos fundamentais constituem - ainda que com intensidade variável, explicitações da dignidade da pessoa, por via de consequência e, ao menos em princípio (já que exceções são admissíveis, consoante já frisado), em cada direito fundamental se faz presente um conteúdo ou, pelo menos, alguma projeção da dignidade da pessoa humana (SARLET, 2011, p. 55).

É vinculado o Estado, os indivíduos e a sociedade em geral por meio da dignidade da pessoa humana, já que a dignidade constitui não somente a garantia de que o indivíduo não deverá ser objeto de humilhações, mas também deve ajudar no desenvolvimento da personalidade de cada pessoa.

Sobre o assunto, afirma Doneda:

A posição da cidadania e da dignidade da pessoa humana como fundamentos da República, juntamente com as garantias de igualdade material e formal 'condicionam o intérprete e o legislador ordinário, modelando todo o tecido normativo infraconstitucional com a tábua axiológica eleita pelo constituinte' e marcam a presença, em nosso ordenamento, de uma cláusula geral da personalidade. Tal cláusula geral representa o ponto de referência para todas as situações nas quais algum aspecto ou desdobramento da personalidade esteja em jogo, estabelecendo com decisão a prioridade a ser dada à pessoa humana, que é o valor fundamental do ordenamento, e está na base de uma série de situações existenciais, nas quais se traduz a sua incessantemente mutável a exigência de tutela (DONEDA, 2002, p. 47).

É proibido, portanto, o retrocesso, onde qualquer supressão e restrição de direito deve ser considerada inconstitucional, se ferir o essencial da dignidade, já que uma vez que deve ser assegurado de maneira permanente o mínimo existencial. 
No que diz respeito ao recurso ordinário, essa questão é contraditória, pois até entre os magistrados alguns defendem que uma decisão que só poderá ser contestada por meio de recurso ordinário já foi transitada em julgado, portanto, não mais irá se falar sobre o princípio da presunção de inocência, quando ainda couber esse recurso.

É preciso que se imponha limites começando antes de nascer até a morte, e estes limites só poderão ser alcançados se estiverem devidamente ligados à dignidade humana. Portanto, todas as práticas bioéticas, devem levar em consideração à dignidade da pessoa humana, como este sendo um valor ético que todos estão obrigados a respeitar, devendo preocupar-se com todas as técnicas de reprodução humana assistida, seleção de sexo, dentre outros.

Sobre o assunto, diz Saldanha:

A dignidade humana compreende não somente a garantia negativa de que o ser humano não seja vítima de ofensas e humilhações, mas também a afirmação positiva do pleno desenvolvimento da personalidade de cada indivíduo. O que certamente só acontecerá se lhe for permitido desenvolvimento natural, sem manipulações externas, exceto para salvar-lhe a vida ou promover-lhe a saúde e desde que não se viole a ordem constitucional vigente (SALDANHA, 2011, $138 \mathrm{f}$.).

Sarlet afirma que:

Dentre as filosofias ocidentais que se ocupam com a dignidade da pessoa humana, podem ser citadas: 1 ) a concepção cristã (dignidade é o valor intrínseco ao ser humano, porque este foi criado à imagem e à semelhança de Deus); 2) o pensamento estóico (dignidade é a qualidade inerente ao ser humano e que o distingue dos outros seres); 3) Tomás de Aquino (autor que dá continuidade à filosofia cristã, acrescentando que também é fundamento da dignidade a autodeterminação de que o ser humano é capaz devido à sua própria natureza); 4) Giovanni Pico Della Mirandola (o ser humano é digno em razão da natureza indefinida que lhe é outorgada por Deus, significando que o homem é capa de ser o que a sua vontade determinar, sendo assim definida a sua natureza); 5) Samuel Pufendorf ( dignidade é a liberdade que o homem tem de optar conforme a sua razão); 6) Immanuel Kant ( o fundamento da dignidade do ser humano é a autonomia ética deste, pois o homem é potencialmente capaz de criar suas leis, autodeterminando sua conduta; o homem é um fim em si mesmo e, por isso, jamais pode ser tratado como objeto); 7) Hegel (dignidade é a qualidade que o ser humano conquista a partir da sua cidadania e a ele é reconhecida); 8) Niklas Luhmann e Peter Hãberle (autores que destacam o aspecto histórico cultural da dignidade). A doutrina jurídica majoritária adota o 
pensamento kantiano no que se refere ao núcleo da noção de dignidade (SARLET, 2011, p. 67).

A dignidade da pessoa humana possui como características a intangibilidade, a irrenunciabilidade e também a inalienabilidade, independendo do seu reconhecimento pelo Direito e dos comportamentos humanos, mesmo que estes não sejam considerados dignos. Sendo dever do estado preservar e promover a dignidade, criando condições para que à mesma seja exercida.

A força jurídica que possui os princípios constitucionais é constatada, conforme pode ser afirmado por José Afonso da Silva:

Em conclusão, a dignidade da pessoa humana constitui um valor que atrai a realização dos direitos fundamentais do homem, em todas as suas dimensões, e, como a democracia é o único regime político capaz de propiciar a efetividade desses direitos, o que significa dignificar o homem, é ela que se revela como o seu valor supremo, o valor que a dimensiona e humaniza (SILVA, 2011, p. 129).

A dignidade da pessoa humana é constituída por um valor juridico que é o mais elevado do ordenamento na Constituição, já que é um valor jurídico supremo. A sociedade que é livre, solidária e também justa somente poderá ser oportunizada quando se elevar a dignidade da pessoa humana como um patamar de fundamento do referido Estado, sendo que este fato priorizou o aumento da personalidade das pessoas que são compostas a sociedade, como podem ser vistos durante o texto constitucional em vários artigos onde constam a dignidade da pessoa humana.

Conforma afirma Bonavides:

Uma Constituição que parte da dignidade humana e de sua proteção deve preocupar-se com que essa dignidade (incluindo suas vinculações) seja vista com um objetivo pedagógico - desde as escolas até a regulamentação da atividade de radiodifusão -, mesmo onde a dignidade não esteja textualmente como constituindo objetivo pedagógico. Da previsão textual da dignidade deriva sua condição do objetivo pedagógico e educativo. A Constituição assume este compromisso perante si própria. Toda a problemática do poder, toda a porfia de legitimação da autoridade e do Estado no caminho da redenção social há de passar, de necessidade, pelo exame do papel normativo do princípio da dignidade da pessoa humana. Sua densidade 
jurídica no sistema constitucional há de ser portanto máxima e se houve reconhecidamente um princípio supremo no trono da hierarquia de normas, esse princípio não deve ser outro senão aquele em que todos os ângulos éticos da personalidade se acham consubstanciados (BONAVIDES, 2014, p. 87).

Conforme versa a Constituição Federal de 1988 em seu artigo $1^{\circ}$, inciso III, que o Estado Democrático de Direito possui como fundamentação a dignidade da pessoa humana, onde se trata do que é denominado de princípio máximo, ou superprincípio, ou macroprincípio. Portanto, o Direito de Família é o que possui a maior ingerência com a Dignidade da Pessoa Humana (TARTUCE, 2017).

Sobre a interação família e dignidade, afirma Gustavo Tepedino:

A família, embora tenha o seu prestígioampliado pela Constituição da República, deixa de tervalor intrínseco, como uma instituição meramente capaz de merecer tutela jurídica pelo simples fato de existir. A família passa a ser valorizada de maneira instrumental,tutelada como um núcleo intermediário de desenvolvimento da personalidade dos filhos e de promoção da dignidade de seusintegrantes" (TEPEDINO, 2011, p. 399).

O referido princípio é de fundamental importância para que se respeite a dignidade da pessoa humana, inclusive vem sido falado com bastante frequência nos meios de comunicação, sendo feito comentários e analisando o mesmo por vários juristas.

Sobre o referido princípio, afirma José Afonso da Silva:

A norma constitucional do artigo $5^{\circ}$, inciso LVII, garante a presunção de inocência por meio de um enunciado negativo universal: "ninguém será considerado culpado até o trânsito em julgado de uma sentença penal condenatória”. o trânsito em julgado se dá quando a decisão não comporta mais recurso ordinário, especial ou extraordinário“" (SILVA, 2011, p. 159).

No que diz respeito ao recurso ordinário, essa questão é contraditória, pois até entre os magistrados alguns defendem que uma decisão que só poderá ser contestada por meio de recurso ordinário já foi transitada em julgado, portanto, não mais irá se falar sobre o princípio da presunção de inocência, quando ainda couber esse recurso. 


\section{CONSIDERAÇÕES FINAIS}

O presente trabalho, procurou, a partir de uma breve análise, evidenciar a passagem do Devarim 19:21, entre outras passagens contidas no livro do Tanah.

Buscamos verificar um direcionamento de justiça como um lema de caráter social, podendo perceber questões principiológicas de direito processual.

Verificou-se que as normas judaicas refletiam, como ainda refletem, mesmo diante da então vigente Lei de Talião, uma preocupação com a aplicabilidade da justiça, buscando, dessa forma, afastar-se de penalizações injustas.

Possível foi visualizar que a sociedade, cujo ideal sejam os valores e as virtudes humanas mais sublimes, tem sua fundação baseada em natureza religiosa, seja ela decorrente de uma fé genuína ou mitológica.

Desde os primórdios civilizatórios, a religião e o Direito, regem o convívio dos homens, e sempre coexistiam em harmonia. As sociedades compreendiam isso de forma uma, compondo suas bases morais.

Restou claro como a Religião, o Direito e a condição humana fazem parte da estrutura da realidade. Embora não comportem toda a estrutura da realidade, pois esta detém uma complexidade tão grande, que só pertence ao entendimento de Deus, temos de concluir que a aceitação da constatação dessas verdades não só produz um espírito sadio ao homem como o auxiliam a viver no melhor no mundo em que foi colocado.

Temos que a nossa Constituição da República Federativa do Brasil nos ensina acerca da obrigatoriedade de o Estado fornecer a dignidade às pessoas, por meio do princípio da dignidade da pessoa humana. Tal princípio é de caráter normativo amplo, já que demonstra reflexo mediante todo o sistema político, social e também jurídico. Também traz de forma veemente a importância que o Estado consegue atribuir à pessoa humana já que aquele existe pelo motivo desta.

Dentro dessa ótica, observamos que o Estado tem o dever, em nível constitucional, de propiciar a dignidade da pessoa humana a todos, que em seu território encontram-se, e tal dignidade encontra na justiça um de seus momentos. 


\section{REFERÊNCIAS BIBLIOGRÁFICAS}

ALARCÓN, Pietro de Jesús Lora. Patrimonio Genético Humano e sua proteção na Constituição Federal de 1988. São Paulo: Editora Método, 2014.

ARISTÓTELES. A política. Introdução de Ivan Lins; tradução de Nestor Silveira Chaves - [Ed. especial] - Rio de Janeiro, Nova Fronteira, 2017

BARROSO, Luis Roberto. Curso de direito constitucional contemporâneo: os conceitos fundamentais e a construção do novo modelo. São Paulo: Saraiva, 2009.

BONAVIDES, Paulo. Curso de Direito Constitucional. 4.ed. São Paulo: Malheiros, 2014.

BRASIL. Constituição Federal de 1988. In: CESPÉDES, Lívia; ROCHA, Fabiana Dias da. Vade mecum. 22. ed. São Paulo: Saraiva, 2º sem. 2016.

BROTERO, José Maria de Avellar (ou "Conselheiro Brotero"). A filosofia do Direito Constitucional. São Paulo: Malheiros Editores LTDA, 2007.

CRUSEMANN, Frank. A Torá - Teologia e história social da lei do Antigo

Testamento. Petrópolis: Vozes, 2002, 2a edição.

DONEDA, Daniel. Os direitos da personalidade no novo Código Civil. In TEPEDINO, Gistavo (coord.). A parte geral do Novo Código Civil: Estudos na perspectiva civilconstitucional. Rio de Janeiro: Renovar, 2002.

FACCIOLLA, Branca Lescher. A Lei de Moisés - Torá - como Fonte de Direito. São Paulo: Rcs Editora, 2005.

GARCIA, Maria. Limites da ciência: A dignidade da pessoa humana: A ética da responsabilidade. São Paulo: Editora Revista dos Tribunais, 2004.

GARDNER, E. Clinton. Fé Bíblica e Ética Social. Trad. Francisco Penha Alves. São Paulo: Aste, 1965.

GRUNWALDT, Klaus, Olho por olho, dente por dente? - O Direito no Antigo Testamento. São Paulo: Loyola, 2009.

LIMA, Máriton Silva. O Direito, o Justo e a Justiça. Um estudo à luz da Bíblia. Jus Navigandi, Teresina, ano 11, $\mathrm{n}^{\mathrm{o}}$ 1436, 7 de junho de 2007. Disponível em http://jus2.uol.com.br/doutrina/texto.asp?id=9982. Acesso em: 21/07/2008. 
MEISTER, Mauro Fernando. Olho por olho: A lei de Talião no contexto bíblico. Fides

Reformata XII, $\mathrm{n}^{\mathrm{o}}$ 1, p. 57-71, $2007 . \quad$ Disponível em http://www.mackensie.edu.br/fides_reformataXII/pdf. Acesso em 12/06/2008.

MONTANELLI, Indro. História de Roma. São Paulo: IBRASA, 1961.

História dos Gregos. São Paulo: IBRASA, 1962.

MORAES, Alexandre de. Direito Constitucional. 29ª ed. São Paulo: Atlas, 2013.

NASSER, José Monir. Expedições pelo mundo da cultura: Os Lusíadas/Fédon. Curitiba: SESI/PR, 2014.

NERY Júnior, Nelson; NERY, Rosa Maria de Andrade. Constituição Federal comentada e legislação constitucional. 2 ed. São Paulo: Revista dos Tribunais. 2006.

REALE, Miguel. Lições preliminares de direito. 27 ed. São Paulo: Saraiva, 2002.

SALDANHA, Nelson. Pela preservação do humano: antropologia filosófica e teoria política. 2ed. São Paulo: A Girafa, 2011.

SARLET, Ingo Wolfgang. A eficácia dos direitos fundamentais. Porto Alegre: Livraria do Advogado, $10^{\text {a }}$ ed.,2011.

SILVA, José Afonso da. Curso de Direito Constitucional Positivo. 27 ed. São Paulo: Malheiros, 2011.

SILVA, José Afonso da. Direito Constitucional Positivo. 31 ed. Malheiros: São Paulo, 2008.

SKA, Jean-Louis, O direito de Israel no Antigo Testamento, in Mies, Françoise (org.), Bíblia e direito - O espírito das leis. São Paulo: Loyola, p. 17-46.

SOUSA, José Pedro Galvão de. Iniciação à Teoria do Estado. $2^{\circ}$ ed. São Paulo: Ed. Revista dos Tribunais, 1976.

. A Constituição e os Valôres da Nacionalidade. São

Paulo: José Bushatsky, 1971. 
TANAH COMPLETO - Hebraico e Português. São Paulo: Editora e Livraria Sêfer Ltda, 2018.

TEPEDINO, Gustavo. Temas de Direito Civil. Rio de Janeiro: Renovar, 2011.

Recebido em: 01/06/2021

Aprovado em: 25/06/2021

Publicado em: 30/06/2021 